\title{
Obesitas, body image, dan perasaan stres pada mahasiswa di Daerah Istimewa Yogyakarta
}

Obesity, body image, and perceived stress among college students in Yogyakarta

Dyah Ayu Kusuma Wardani ${ }^{1}$, Emy Huriyati ${ }^{1}$, Mustikaningtyas ${ }^{2}$, Janatin Hastuti ${ }^{3}$

\begin{abstract}
Background: Obesity can lead to various health problems including psychosocial problems. Obesity also relates to body image which may affects psychosocial health. Objective: To examine the relationship between obesity, body image, and perceived stress among college students in Yogyakarta Province. Method: This study is a cross sectional design in 150 college students (75 boys and 75 girls) at Universitas Gadjah Mada and Universitas Technology Yogyakarta. Perceived stress was measured using 10 items of the Perceived Stress Scale (PSS-10), body image was evaluated using 16 items of the Body Shape Questionnaire (BSQ-16) and obesity was estimated using percentage of body fat calculated from anthropometric measurements. Chi-square test, Spearman correlation analysis, and odds ratio were used to test the hypotheses. Results: There was significant correlation between obesity and body image in male $(r=0.32 ; p<0.01)$ and female students $(r=0.23 ; p<0.05)$. Obese male students were 7 times likely to have negative body image than non-obese male students. While, no significant relationship was found between obesity and perceived stress, non-obese students had almost two times likely to perceive stress. Similarly, body image was not significantly related to perceived stress in male and female students, however, it was likely that students with negative body image had about 1,5 times to feel stress than those with positive body image. Conclusion: Obesity was significantly associated with body image among male and female college students. However, no significant relationship was found between obesity and perceived stress as well as between body image and perceived stress among the students.
\end{abstract}

KEY WORDS: body image; college students; obesity; perceived stress; percentage of body fat

\begin{abstract}
ABSTRAK
Latar belakang: Obesitas dapat menyebabkan berbagai risiko kesehatan termasuk gangguan psikososial. Obesitas juga diketahui berhubungan dengan body image yang dapat menimbulkan efek kesehatan psikososial. Tujuan: Mengetahui hubungan antara obesitas, body image, dan perasaan stres pada mahasiswa di Yogyakarta. Metode: Desain penelitian cross sectional pada 150 mahasiswa (75 laki-laki dan 75 perempuan) di Universitas Gadjah Mada dan Universitas Teknologi Yogyakarta. Perasaan stres diukur menggunakan Perceived Stress Scale - 10 item scale (PSS-10), body image menggunakan Body Shape Questionnaire - 16 item (BSQ-16), dan obesitas diukur dari persen lemak tubuh berdasarkan ukuran antropometri. Analisis data menggunakan uji Chi-Square, korelasi Spearman, dan odds ratio. Hasil: Terdapat hubungan signifikan antara obesitas dengan body image pada mahasiswa laki-laki $(\mathrm{r}=0,32 ; \mathrm{p}<0,01)$ dan perempuan $(\mathrm{r}=0,23 ; \mathrm{p}<0,01)$. Mahasiswa laki-laki obes memiliki potensi $7 \mathrm{kali}$ lebih besar untuk mempunyai body image negatif dibandingkan mahasiswa laki-laki tidak obes. Meskipun tidak terdapat hubungan signifikan antara obesitas dengan perasaan stres baik pada mahasiswa laki-laki $\left(x^{2}=1,08 ; \mathrm{r}=0.12\right)$ maupun perempuan $\left(\mathrm{x}^{2}=1,45\right.$; $\mathrm{r}=0,14)$, tetapi mahasiswa non-obes memiliki peluang hampir 2 kali untuk merasa stres dibandingkan mahasiswa obes. Demikian juga body image dan perasaan stres tidak berhubungan signifikan pada mahasiswa laki-laki $\left(x^{2}=0,50 ; \mathrm{r}=0,480\right)$ dan perempuan $\left(x^{2}=0,55 ; r=0,09\right)$, tetapi mahasiswa dengan body image negatif mempunyai potensi 1,5 kali lebih besar untuk merasa stres daripada mahasiswa dengan body image positif. Simpulan: Body image berhubungan signifikan dengan obesitas pada mahasiswa laki-laki maupun perempuan. Namun, tidak terdapat hubungan signifikan antara body image dan perasaan stres, serta antara obesitas dan perasaan stres pada semua mahasiswa.
\end{abstract}

KATA KUNCI: body image; mahasiswa; obesitas; perasaan stres; persen lemak tubuh

\section{PENDAHULUAN}

Obesitas merupakan salah satu permasalahan gizi yang prevalensinya terus meningkat di Indonesia, di samping permasalahan gizi kurang yang belum dapat teratasi. Data Riset kesehatan dasar (Riskesdas) oleh

\footnotetext{
Program Studi Gizi Kesehatan, Fakultas Kedokteran Universitas Gadjah Mada

${ }^{2}$ Badan Kependudukan dan Keluarga Berencana Nasional Daerah Istimewa Yogyakarta

${ }^{3}$ Korespondensi: Laboratorium Bioantropologi \& Paleoantropologi, Fakultas Kedokteran Universitas Gadjah Mada. Jl. Medika, Sekip, Sleman, Yogyakarta 55281, Telp: 0274-552577, Fax: 0274-552577,e-mail: janatin.hastuti@ugm. ac.id
} 
Kementerian Kesehatan Republik Indonesia (Kemenkes RI) tahun 2013 menunjukkan kecenderungan status gizi dewasa mengalami peningkatan untuk masalah pendek-gemuk dan normal-gemuk. Prevalensi obesitas pada laki-laki dewasa sebanyak $19,7 \%$ pada tahun 2013 , lebih tinggi dari tahun 2007 (13,9\%) dan 2010 (7,8\%). Provinsi Daerah Istimewa Yogyakarta termasuk dalam 16 provinsi dengan prevalensi obesitas teratas dalam skala nasional (1).

Konsekuensi obesitas terhadap kesehatan bervariasi mulai dari kematian prematur sampai kualitas hidup yang rendah. Pada umumnya, obesitas dikaitkan dengan noncommunicable disease seperti non-insulin-dependent diabetes melitus (NIDDM), penyakit kardiovaskuler, kanker, dan berbagai gangguan psikososial (2). Selain komplikasi fisik dari obesitas, juga dapat terjadi komplikasi sosial dan emosional mayor. Beberapa penderita obesitas mengeluhkan masalah kecemasan, depresi, dan penarikan diri dari sosial karena masalah berat badan mereka (3). Kegemukan ditinjau dari segi psikososial merupakan beban bagi individu yang bersangkutan karena dapat menghambat kegiatan jasmani, sosial, dan psikologis. Selain itu, akibat bentuk yang kurang menarik, sering menimbulkan problem dalam pergaulan dan seseorang menjadi rendah diri dan merasa putus asa (2).

Perempuan dengan status berat badan overweight dan obes cenderung memiliki ketidakpuasan body image yang lebih besar dibanding perempuan dengan berat badan normal (4). Ketidakpuasan terhadap bentuk dan ukuran tubuh menjadi suatu hal yang endemik bagi perempuan dan disebut "normative discontent". Lebih lanjut, prevalensi perempuan dengan berat badan normal atau underweight yang tidak puas terhadap tubuhnya cukup besar dibandingkan laki-laki yaitu sebesar 41\% dibandingkan 53\% pada perempuan (5). Penelitian lain juga menemukan bahwa remaja obes memiliki kemungkinan 11,9 kali lebih besar tidak puas dengan body image-nya daripada remaja tidak obes (6).

Body image yang buruk dapat menimbulkan efek utama kesehatan psikososial, misalnya stres di masa yang akan datang (7). Stres psikososial yang berkelanjutan menimbulkan gejala-gejala fisik seperti depresi, disforia, insomnia, keletihan, mudah tersinggung, rentan terhadap infeksi, serta berkurangnya performa fisik dan mental (8). Stres juga dapat menyebabkan peningkatan tekanan darah, aterosklerosis, penyakit kardiovaskuler, menurunkan respon sistem imun, dan bermacam penyakit lain seperti asma (9). Penelitian pada mahasiswa di Latina menunjukkan adanya hubungan signifikan antara stres akulturatif dengan ketidakpuasan body image dan memungkinkan memicu eating disorder (10). Ketidakpuasan terhadap tubuh juga merupakan satu di antara penyebab stres pada remaja (11).

Kebanyakan penelitian mengunakan metode untuk menentukan status obesitas dengan mengukur indeks massa tubuh (IMT). Namun, kelemahan IMT adalah tidak mampu mengukur secara langsung kandungan lemak tubuh. Dengan demikian, dalam penentuan obesitas dengan mengacu pada definisi World Health Organization (WHO) yaitu kondisi lemak tubuh yang berlebihan, maka identifikasi obesitas sebaiknya dilakukan berdasarkan pengukuran komponen lemak tubuh. Penentuan obesitas berdasarkan IMT semata dapat menyebabkan misklasifikasi obesitas (12). Misalnya, pada IMT yang sama diketahui bahwa penduduk Singapura etnis Cina mempunyai persen lemak tubuh yang paling besar dibandingkan penduduk Cina di Beijing dan penduduk Belanda (13). Oleh karena itu, penelitian ini menggunakan penentuan obesitas berdasarkan persentase lemak tubuh (PLT).

Penelitian mengenai body image yang telah ada kebanyakan dilakukan kepada remaja putri siswa Sekolah Menengah Pertama (SMP) atau Sekolah Menengah Atas (SMA), tetapi jarang dilakukan pada kelompok usia dewasa atau mahasiswa. Penelitian mengenai hubungan body image, obesitas, dan segi psikososial yang ditunjukkan dengan adanya perasaan stres pada mahasiswa belum banyak ditemukan di Indonesia. Sementara itu, periode umur mahasiswa merupakan periode yang rentan terhadap gangguan body image maupun stress $(10,11)$ sehingga penelitian terhadap kelompok mahasiswa penting untuk dilakukan. Penelitian ini bertujuan untuk mengetahui hubungan antara obesitas, body image, dan perasaan stres pada mahasiswa di Daerah Istimewa Yogyakarta.

\section{BAHAN DAN METODE}

Penelitian ini merupakan penelitian analitik dan menggunakan desain penelitian cross sectional. 
Penelitian dilaksanakan pada bulan September-Desember 2014 di Fakultas Kedokteran dan Fakultas Ilmu Budaya Universitas Gadjah Mada (UGM) dan Fakultas Bisnis dan Teknologi Informasi, Universitas Teknologi Yogyakarta (UTY). Populasi penelitian ini adalah mahasiswa di Yogyakarta. Sementara subjek pada penelitian ini diambil dari populasi yang memenuhi kriteria inklusi yaitu: 1) berstatus sebagai mahasiswa S1 di Yogyakarta, 2) bersedia menjadi responden dalam penelitian ini, dan 3) tidak cacat fisik dan mental serta dieksklusi jika tidak mengikuti seluruh prosedur penelitian. Seluruh responden menyetujui dan menandatangani informed consent. Ethical clearance diperoleh dari Komite Etik Penelitian Kedokteran dan Kesehatan Fakultas Kedokteran UGM. Besar sampel diperhitungkan dengan rumus perhitungan besar sampel untuk rerata satu populasi (14). Jumlah sampel yang diteliti adalah 150 orang (75 laki-laki dan 75 perempuan) dengan pengambilan sampel dilakukan secara quota sampling (15).

Variabel dalam penelitian ini terdiri dari variabel terikat yaitu perasaan stres pada mahasiswa dan variabel bebas yakni obesitas dan body image pada mahasiswa. Perasaan stres responden diukur menggunakan kuesioner yaitu perceived stress scale 10 item (PSS-10) (16) dengan nilai Cronbach's alpha 0,78 (17). Hasil pengukuran menggunakan PSS-10 adalah menjumlahkan seluruh skor total masing-masing pertanyaan, kecuali untuk nomor 4,5,7, dan 8 diberi skor kebalikan dari skala yang digunakan $(0=4,1=2,2=2,3=1$, dan $0=4)$. Hasil pengukuran perasaan stres dengan PSS-10 dikategorikan menjadi dua yaitu merasa stres apabila skor total $>16$ dan tidak merasa stres apabila skor total $\leq 16$, berdasarkan angka rerata skor PSS-10 pada sampel yang memiliki perilaku mencari bantuan untuk mengatasi stres adalah 16 dan diasumsikan memiliki tingkat stres yang lebih tinggi (17). Penelitian pendahuluan dilakukan untuk menguji reliabilitas dan validitas PSS-10 yang telah diterjemahkan ke dalam Bahasa Indonesia. Hasil uji reliabilitas internal serta content validity per item pertanyaan menunjukkan nilai Cronbach's alpha 0,716 pada pretest dan 0,842 pada post-test serta koefisien korelasi 0,665.

Obesitas diukur menggunakan PLT yang dihitung dari perhitungan rumus berdasarkan hasil pengukuran tebal lipatan kulit (18). Kategori obesitas untuk laki- laki disebut obesitas apabila PLT lebih dari 25 dan untuk perempuan PLT lebih dari 35 (19). Pada laki-laki, pengukuran tebal lipatan kulit yang perlu dilakukan adalah pengukuran tebal lipatan kulit abdominal dan triceps. Sementara pada perempuan, pengukuran tebal lipatan kulit yang perlu dilakukan adalah pengukuran tebal lipatan triceps dan crista iliaca. Pengukuran antropometri yang dilakukan dalam penelitian ini mengikuti standar dari The International Society for the Advancement of Kinanthropometry (ISAK) 2006 (20). Pengukuran body image menggunakan body shape questionnaire 16 item (BSQ-16) (21). Instrumen ini sudah diterjemahkan dalam Bahasa Indonesia dan diuji reliabilitasnya dengan koefisien Cronbach's alpha >0,9, artinya memiliki reliabilitas internal yang sangat baik (18). Hasil pengukuran BSQ-16 merupakan penjumlahan skor total dari masing-masing pertanyaan. Body image kemudian dikategorikan menjadi body image negatif apabila skor total lebih dari kuartil 1 ( $>\mathrm{Q} 1)$ dan body image positif apabila skor total kurang dari atau sama dengan kuartil $1(\leq \mathrm{Q} 1)(22)$.

Analisis univariat untuk melihat distribusi frekuensi masing-masing variabel meliputi jumlah dan persentase karakteristik responden, deskripsi ukuran antropometri (rerata dan standar deviasi), dan distribusi frekuensi variabel yang diteliti (body image, obesitas, dan perasaan stres). Analisis bivariat untuk melihat hubungan antara variabel bebas dan variabel terikat untuk menguji hipotesis menggunakan uji Chi-Square dengan tingkat kemaknaan 95\%. Uji t digunakan untuk mengetahui perbedaan karakteristik antara mahasiswa laki-laki dan perempuan.

\section{HASIL}

Responden dalam penelitian ini adalah 150 mahasiswa (75 laki-laki dan 75 perempuan) di Fakultas Kedokteran dan Fakultas Ilmu Budaya UGM, serta mahasiswa di Fakultas Bisnis dan Teknologi Informasi UTY angkatan 2010 sampai 2014. Umur responden berkisar antara 19-24 tahun yang berarti termasuk kategori kelompok umur dewasa (23) dengan rerata umur 20,6 $\pm 1,0$ tahun. Berdasarkan pendidikan, pekerjaan, dan penghasilan ayah dan ibu responden dapat disimpulkan 
bahwa umumnya responden berasal dari keluarga kelas menengah ke bawah dilihat dari persentase penghasilan paling banyak antara $<2,5$ juta dan 2,5-5 juta (Rp/bulan) serta tingkat pendidikan terakhir juga paling banyak maksimal SLTA.

Karakteristik mahasiswa seperti ditampilkan pada Tabel 1 menunjukkan bahwa rerata IMT mahasiswa laki-laki lebih besar secara signifikan $(\mathrm{p}<0,05)$ daripada mahasiswa perempuan yaitu berturut-turut $22,4 \mathrm{~kg} / \mathrm{m}^{2}$ dan $20,9 \mathrm{~kg} / \mathrm{m}^{2}$. Sebaliknya, rerata PLT lebih besar secara signifikan $(\mathrm{p}<0,01)$ pada mahasiswa perempuan $(31,1 \pm$ $3,6 \%)$ daripada mahasiswa laki-laki $(21,5 \pm 6,8 \%)$. Rerata skor BSQ-16 juga lebih besar secara signifikan $(\mathrm{p}<0,01)$ pada mahasiswa perempuan $(42,7 \pm 14,1)$. Namun, tidak terdapat perbedaan signifikan pada rerata skor PSS-10 antara mahasiswa laki-laki dan perempuan yaitu berturutturut sebesar 18,9 \pm 5,2 dan 19,2 \pm 4,9.

Berdasarkan IMT, mahasiswa laki-laki lebih banyak $(25,4 \%)$ mengalami obesitas dibandingkan mahasiswa perempuan (12\%). Menurut indikator PLT, obesitas juga lebih banyak terdapat pada mahasiswa laki-laki $(29,4 \%)$ dibandingkan mahasiswa perempuan $(8,7 \%)$. Analisis statistik menunjukkan tidak terdapat perbedaan signifikan terhadap distribusi kategori obesitas pada IMT maupun PLT antara laki-laki dan perempuan. Secara umum, prevalensi obesitas lebih besar

Tabel 1. Rerata indeks masa tubuh, persen lemak tubuh dan skor PSS-10 dan BSQ-16 mahasiswa laki-laki dan perempuan

\begin{tabular}{lccc}
\hline \multirow{2}{*}{ Variabel } & Laki-laki $(\mathbf{n}=\mathbf{7 5})$ & Perempuan $(\mathbf{n}=\mathbf{7 5})$ & \multirow{2}{*}{$\mathbf{p}$} \\
\cline { 2 - 4 } & Rerata \pm SD & Rerata \pm SD & \\
\hline $\mathrm{IMT}^{1}$ & $22,4 \pm 5,1$ & $20,9 \pm 3,1$ & 0,035 \\
\hline $\mathrm{PLT}^{2}$ & $21,5 \pm 6,8$ & $31,1 \pm 3,6$ & 0,000 \\
\hline $\mathrm{BSQ}^{2} 16$ & $36,7 \pm 13,2$ & $42,7 \pm 14,1$ & 0,008 \\
\hline PSS-10 & $18,9 \pm 5,2$ & $19,2 \pm 4,9$ & 0,697 \\
\hline
\end{tabular}

${ }^{1}$ IMT: indeks massa tubuh; ${ }^{2} \mathrm{PLT}$ : persen lemak tubuh menggunakan kategori PLT (23,3\%) daripada kategori IMT (18,7\%) (Tabel 2).

Distribusi kategori body image dan perasaan stres seperti ditampilkan pada Tabel 3 menunjukkan bahwa keseluruhan mahasiswa yang memiliki body image negatif lebih banyak (74\%) daripada mahasiswa dengan body image positif (26\%). Sementara itu, prevalensi body image negatif sedikit lebih tinggi pada perempuan (80\%) dibanding pada laki-laki (68\%). Prevalensi mahasiswa dengan perasaan stres total sebanyak 105 respoden (70\%) dengan proporsi hampir sama antara mahasiswa laki-laki dan perempuan secara berturut-turut sebesar $72 \%$ dan $68 \%$.

Tabel 4 menunjukkan hubungan antara obesitas dan body image pada mahasiswa laki-laki dan perempuan. Proporsi mahasiswa non-obes dengan body image negatif cukup besar yaitu 58,5\% pada mahasiswa laki-laki dan $75,8 \%$ pada mahasiswa perempuan. Angka tersebut lebih kecil dibandingkan mahasiswa dengan obesitas yang memiliki body image negatif yaitu sebesar 90,9\% pada laki-laki dan $100 \%$ pada perempuan. Tidak seorangpun mahasiswa perempuan obes yang memiliki body image positif dan mahasiswa laki-laki hanya sebanyak $0,1 \%$. Terdapat korelasi yang lemah namun signifikan antara

Tabel 3. Distribusi frekuensi body image dan perasaan stres pada mahasiswa laki-laki dan perempuan

\begin{tabular}{|c|c|c|c|c|c|c|}
\hline \multirow{2}{*}{ Variabel } & \multicolumn{2}{|c|}{ Laki-laki } & \multicolumn{2}{|c|}{ Perempuan } & \multicolumn{2}{|c|}{ Total } \\
\hline & $n$ & $\%$ & $\mathbf{n}$ & $\%$ & $\mathbf{n}$ & $\%$ \\
\hline \multicolumn{7}{|l|}{ Body image } \\
\hline Negatif $^{1}$ & 51 & 68 & 60 & 80 & 111 & 74 \\
\hline Positif $^{2}$ & 24 & 32 & 15 & 20 & 39 & 26 \\
\hline \multicolumn{7}{|l|}{ Perasaan Stres } \\
\hline Merasa stres ${ }^{3}$ & 54 & 72 & 51 & 68 & 105 & 70 \\
\hline Tidak merasa stres ${ }^{4}$ & 21 & 28 & 24 & 32 & 45 & 30 \\
\hline
\end{tabular}

${ }^{1}$ Negatif $>\mathrm{Q} 1 ;{ }^{2}$ Positif $\leq \mathrm{Q} 1 ;{ }^{3}$ Merasa stres $>16 ;{ }^{4}$ Tidak merasa stres $\leq 16$; $\chi^{2}$ body image $(\mathrm{p}=0,136)$ dan perasaan stress $(\mathrm{p}=\backslash 0,722)$

Tabel 2. Distribusi obesitas pada mahasiswa laki-laki dan perempuan

\begin{tabular}{|c|c|c|c|c|c|c|c|c|c|c|c|c|}
\hline \multirow{3}{*}{$\begin{array}{l}\text { Kategori } \\
\text { status gizi }\end{array}$} & \multicolumn{4}{|c|}{ IMT $^{1}$} & \multirow{2}{*}{\multicolumn{2}{|c|}{ Total }} & \multicolumn{4}{|c|}{ PLT $^{2}$} & \multirow{2}{*}{\multicolumn{2}{|c|}{ Total }} \\
\hline & \multicolumn{2}{|c|}{ Laki-laki } & \multicolumn{2}{|c|}{ Perempuan } & & & \multicolumn{2}{|c|}{ Laki-laki } & \multicolumn{2}{|c|}{ Perempuan } & & \\
\hline & $\mathbf{n}$ & $\%$ & n & $\%$ & n & $\%$ & n & $\%$ & $\mathbf{n}$ & $\%$ & n & $\%$ \\
\hline Obesitas & 19 & 25,4 & 9 & 12 & 28 & 18,7 & 22 & 29,4 & 13 & 17,4 & 35 & 23,3 \\
\hline Non-Obesitas & 56 & 74,6 & 66 & 88 & 122 & 81,3 & 53 & 70,6 & 62 & 82,6 & 115 & 76,7 \\
\hline
\end{tabular}

${ }^{1}$ IMT: indeks masa tubuh, obesitas $\geq 25 \mathrm{~kg} / \mathrm{m}^{2}$, non-obesitas $<25 \mathrm{~kg} / \mathrm{m}^{2}$;

${ }^{2}$ PLT: persen lemak tubuh, obesitas jika laki-laki $>35 \%$ dan perempuan $>25 \% ; \chi^{2}$ IMT $(p=0,058)$ dan PLT $(p=0,122)$ 
Dyah Ayu Kusuma Wardani, dkk: Obesitas, body image, dan perasaan stres pada mahasiswa di Daerah Istimewa Yogyakarta

Tabel 4. Hubungan obesitas dan body image pada mahasiswa laki-laki dan perempuan

\begin{tabular}{|c|c|c|c|c|c|c|c|}
\hline \multirow{3}{*}{ Variabel } & \multicolumn{4}{|c|}{ Body image } & \multirow{3}{*}{$\chi^{2}$} & \multirow{3}{*}{$\begin{array}{c}\text { OR } \\
(95 \% \mathrm{CI})\end{array}$} & \multirow{3}{*}{$r$} \\
\hline & \multicolumn{2}{|c|}{ Negatif } & \multicolumn{2}{|c|}{ Positif } & & & \\
\hline & $\mathbf{n}$ & $\%$ & $\mathrm{n}$ & $\%$ & & & \\
\hline \multicolumn{8}{|l|}{ Laki-laki } \\
\hline Obesitas $(n=22)$ & 20 & 90,9 & 2 & 0,1 & $7,509^{* *}$ & $7,10^{2}$ & $0,32^{* *}$ \\
\hline Non-obesitas $(n=53)$ & 31 & 58,5 & 22 & 41,4 & & $(1,50-33,53)$ & \\
\hline Subtotal & 51 & & 24 & & & & \\
\hline \multicolumn{8}{|l|}{ Perempuan } \\
\hline Obesitas $(n=13)$ & 13 & 100 & 0 & 0 & $3,931^{*}$ & a & $0,23^{*}$ \\
\hline Non-obesitas $(n=62)$ & 47 & 75,8 & 15 & 31,9 & & & \\
\hline Subtotal & 60 & & 15 & & & & \\
\hline \multirow[t]{2}{*}{ Total } & 111 & & 39 & & $9,764^{* *}$ & & \\
\hline & & & \multicolumn{2}{|c|}{$\chi^{2} \mathrm{MH}$} & $9,858^{* *}$ & & \\
\hline
\end{tabular}

* $\mathrm{p}<0,05 ; * * \mathrm{p}<0,01 ; \chi^{2} \mathrm{MH}$ : Chi-Square Mantel Haenszel; OR: Mantel-Haenzel Common Odds Ratio;

r: koefisien korelasi Spearman; a: OR tidak bisa dihitung karena salah satu sel mempunyai nilai "0"

Tabel 5. Hubungan obesitas dan body image terhadap perasaan stres pada mahasiswa laki-laki dan perempuan

\begin{tabular}{|c|c|c|c|c|c|c|c|}
\hline \multirow{3}{*}{ Variabel } & \multicolumn{4}{|c|}{ Perasaan stres } & \multirow{3}{*}{$\chi^{2}$} & \multirow{3}{*}{ OR } & \multirow{3}{*}{$\mathbf{r}$} \\
\hline & \multicolumn{2}{|c|}{ Merasa stres } & \multicolumn{2}{|c|}{ Tidak merasa stres } & & & \\
\hline & $\mathbf{n}$ & $\%$ & $\mathbf{n}$ & $\%$ & & & \\
\hline \multicolumn{8}{|l|}{ Laki-laki } \\
\hline Obesitas $(n=22)$ & 14 & 63,6 & 8 & 36,4 & 1,080 & 0,57 & 0,12 \\
\hline Non-obesitas $(\mathrm{n}=53)$ & 40 & 75,5 & 13 & 24,5 & & $(0,19-1,66)$ & \\
\hline Subtotal & 54 & & 21 & & & & \\
\hline \multicolumn{8}{|l|}{ Perempuan } \\
\hline Obesitas $(n=13)$ & 7 & 53,8 & 6 & 46,2 & 1,448 & 0,48 & 0,14 \\
\hline Non-obesitas $(n=62)$ & 44 & 71,0 & 18 & 39,0 & & $(0,14-1,62)$ & \\
\hline Subtotal & 51 & & 24 & & & & \\
\hline \multirow[t]{2}{*}{ Total } & 105 & & 45 & & 2,174 & 2,10 & \\
\hline & & & \multicolumn{2}{|c|}{$\chi^{2} \mathrm{MH}$} & 1,823 & & \\
\hline \multicolumn{8}{|l|}{ Laki-laki } \\
\hline Body image negatif $(\mathrm{n}=51)$ & 38 & 74,5 & 13 & 25,5 & 0,498 & 1,46 & 0,08 \\
\hline Body image positif $(\mathrm{n}=24)$ & 16 & 66,7 & 8 & 33,3 & & $(0,51-4,20)$ & \\
\hline Subtotal & 54 & & 21 & & & & \\
\hline \multicolumn{8}{|l|}{ Perempuan } \\
\hline Body image negatif $(\mathrm{n}=60)$ & 42 & 70,0 & 18 & 30,0 & 0,551 & 1,56 & 0,09 \\
\hline Body image positif $(\mathrm{n}=15)$ & 9 & 60,0 & 6 & 40,0 & & $(0,48-5,02)$ & \\
\hline Subtotal & 51 & & 24 & & & & \\
\hline \multirow[t]{2}{*}{ Total } & 105 & & 45 & & 0,873 & 0,85 & \\
\hline & & & \multicolumn{2}{|c|}{$\chi^{2} \mathrm{MH}$} & 0,655 & & \\
\hline
\end{tabular}

$\chi^{2}$ MH: Chi-Square Mantel Haenszel; OR: Mantel-Haenzel Common Odds Ratio; r: koefisien korelasi Spearman

obesitas dengan body image baik pada mahasiswa lakilaki maupun perempuan dengan nilai $\mathrm{r}$ masing-masing 0,32 (laki-laki; $\mathrm{p}<0,01$ ) dan 0,23 (perempuan; $\mathrm{p}<0,05$ ). Nilai OR menunjukkan bahwa mahasiswa laki-laki dengan body image negatif mempunyai risiko 7 kali lebih besar untuk memiliki body image negatif daripada mahasiswa laki-laki yang non-obes.

Hubungan antara obesitas dan body image terhadap perasaan stres ditampilkan pada Tabel 5. Proporsi mahasiswa non-obes yang merasa stres lebih besar 
daripada mahasiswa non-obes yang tidak merasa stres (laki-laki 75,5\%, perempuan 71,0\%). Demikian juga, mahasiswa obes yang merasa stres juga lebih banyak dibandingkan mahasiswa obes yang tidak merasa stres yaitu $63,6 \%$ pada mahasiswa laki-laki dan 53,8\% pada mahasiswa perempuan. Sementara itu, proporsi mahasiswa yang memiliki body image negatif dan merasa stres lebih besar dibanding yang memiliki body image positif dan merasa stres pada mahasiswa laki-laki maupun perempuan secara berturut-turut $74,5 \%$ vs $66,7 \%$ dan $70,0 \%$ vs $60,0 \%$ pada mahasiswa laki-laki dan perempuan. Namun, proporsi mahasiswa yang tidak merasa stres dengan body image positif juga secara proporsional lebih besar dibandingkan mahasiswa yang tidak stress dengan body image negatif baik pada laki-laki (33,3 vs 25,5\%) maupun perempuan (40 vs 30\%). Uji Chi-Square menunjukkan tidak terdapat hubungan yang signifikan antara obesitas dan perasaan stres maupun antara body image dan perasaan stres baik pada mahasiswa laki-laki maupun perempuan. Namun, OR menunjukkan bahwa mahasiswa dengan obesitas memiliki risiko $0,5 \mathrm{kali}$ untuk merasa stres dibandingkan mahasiswa yang nonobes, serta mahasiswa yang memiliki body image negatif memiliki risiko 1,5 kali untuk merasa stres daripada mahasiswa yang memiliki body image positif, dengan angka kecenderungan pada mahasiswa laki-laki sedikit lebih besar daripada mahasiswa perempuan.

\section{BAHASAN}

Penelitian ini mengkaji tentang hubungan antara obesitas, body image, dan perasaan stres pada mahasiswa di Yogyakarta. Hasil penelitian menunjukkan terdapat hubungan yang signifikan antara obesitas dengan body image baik pada mahasiswa laki-laki maupun perempuan. Mahasiswa laki-laki dengan obesitas memiliki potensi lebih besar untuk mempunyai body image negatif dibandingkan mahasiswa laki-laki yang tidak obes. Meskipun tidak terdapat hubungan signifikan antara obesitas dengan perasaan stres, baik pada mahasiswa laki-laki maupun perempuan, tetapi mahasiswa nonobes memiliki peluang lebih besar untuk merasa stres dibandingkan mahasiswa obse. Demikian juga antara body image dengan perasaan stres tidak berhubungan secara signifikan, baik pada mahasiswa laki-laki dan perempuan, tetapi mahasiswa dengan body image negatif mempunyai potensi lebih besar untuk merasa stres daripada mahasiswa dengan body image positif.

Penelitian ini menemukan bahwa tanpa membedakan jenis kelamin, hampir tiga dari empat mahasiswa memiliki body image negatif. Tingginya jumlah responden yang memiliki body image negatif kemungkinan bisa dipengaruhi oleh karena puncak perhatian pada penampilan terjadi pada saat remaja dan usia 20 tahunan. Ketidakpuasan terhadap bentuk dan ukuran tubuh menjadi suatu hal yang endemik bagi perempuan dan disebut "normative discontent". Persentase ketidakpuasan terhadap tubuh ditemukan cukup besar pada perempuan yang memiliki berat badan normal atau underweight, demikian juga pada laki-laki, meskipun dilaporkan lebih rendah namun tidak berbeda signifikan (5). Demikian juga pada penelitian ini, meskipun prevalensi mahasiswa perempuan dengan body image negatif lebih besar daripada laki-laki, tetapi tidak berbeda secara signifikan.

Prevalensi mahasiswa dengan perasaan stres juga cukup tinggi pada penelitian ini. Lebih dari dua-pertiga mahasiswa secara umum merasa stres. Tingginya jumlah responden yang merasa stres bisa dipengaruhi oleh faktor multidimensional (misalnya: sosial, budaya, ekonomi, biologis) yang dialami mahasiswa dan terbukti secara teoritis dan empiris dapat menimbulkan stres (24). Hasil analisis antara perasaan stres dengan karakteristik umum responden menemukan adanya hubungan yang signifikan antara perasaan stres dengan penghasilan ayah dan pendidikan ibu (tidak ditampilkan dalam tabel hasil penelitian). Stres meningkat pada penurunan tingkat pendidikan dan pendapatan. Hal ini juga didukung oleh bukti bahwa peningkatan socioeconomic status (SES) berhubungan dengan penurunan risiko morbiditas dan mortilitas dini (25).

Hasil penelitian ini memperkuat penelitianpenelitian sebelumnya yang menemukan bahwa obesitas dipengaruhi oleh body image. Body image negatif lebih banyak terdapat pada mahasiswa obes daripada non-obes, yaitu lebih dari $90 \%$ dan bahkan $100 \%$ pada mahasiswa perempuan obes. Penelitian pada perempuan-perempuan Jepang menunjukkan bahwa perempuan-perempuan 
Jepang mengalami perubahan body image setelah mengalami kenaikan berat badan sesudah selama 2 bulan tiba di New York. Perubahan body image yang lebih besar terjadi seiring dengan kenaikan berat badan setelah memasuki lingkungan dengan prevalensi obesitas yang lebih tinggi (26). Perempuan dengan overweight dan obesitas memiliki ketidakpuasan body image yang lebih besar dibanding perempuan dengan berat badan normal (4). Tingginya prevalensi body image negatif pada mahasiswa non-obes baik laki-laki maupun perempuan pada penelitian ini perlu mendapatkan perhatian mengingat beberapa penelitian menunjukkan bahwa ketidakpuasan terhadap tubuh merupakan faktor risiko terhadap makan berlebih, sikap dan perilaku makan yang tidak benar, dan obesitas (27). Selain itu, hubungan antara body image dan obesitas bisa terjadi dari arah yang sebaliknya, artinya obesitas juga bisa mempengaruhi body image seseorang. Pada beberapa orang dengan obesitas, banyak yang tidak dapat mengabaikan keadaan tubuhnya dan menjadi tidak puas akan bentuk tubuh mereka (28).

Ketidakpuasan terhadap berat badan merupakan salah satu faktor penggerak penting perilaku diet yang tidak sehat, misalnya diet Yoyo. Perilaku diet tidak sehat dalam hubungannya dengan siklus berat badan biasa terjadi pada populasi (29). Sebagian masyarakat mempunyai pandangan bahwa gemuk atau obes adalah lambang kemakmuran karena kebanyakan obesitas terjadi di daerah perkotaan dan apabila di perdesaan obesitas terjadi pada lurah atau tokoh masyarakat lainnya. Lahirnya pandangan masyarakat bahwa gemuk sebagai lambang kesuksesan merupakan permasalahan tersendiri dalam upaya pencegahan obesitas serta penyakit degeneratif akibat obesitas (30).

Selain itu, merasa gemuk adalah pengalaman yang dilaporkan oleh banyak perempuan, tapi insentitas dan frekuensi perasaan ini muncul jauh lebih banyak pada orang dengan eating disorder (28). Ketidakpuasan terhadap tubuh memiliki faktor risiko yang serius terhadap eating disorder. Terdapat hubungan dua arah antara ketidakpuasan terhadap tubuh dan eating disorder (27) sehingga perasaan stres lebih banyak muncul pada orang dengan eating disorder sedangkan penelitian ini tidak melakukan perlakuan khusus untuk mengidentifikasi adanya eating disorder pada responden.
Hasil penelitian ini menunjukkan tidak ada hubungan yang signifikan antara obesitas dan perasaan stres. Penelitian sebelumnya pada siswa SMP Stella Duce 1 Yogyakarta juga menemukan tidak ada hubungan antara status stres psikososial dengan status gizi (31). Pada penelitian ini, hasil analisis menunjukkan bahwa mahasiswa tanpa obesitas justru memiliki risiko dua kali lebih besar untuk merasa stres dibandingkan mahasiswa dengan obesitas. Hasil ini bertentangan dengan wacana yang menganggap struktur tubuh penderita obesitas memberatkan untuk bergerak sehingga membuat adanya gambaran bahwa seorang penderita obesitas gagal mendapat keadilan sosial dan kekerasan secara psikis. Ini berkaitan dengan sebutan atau istilah yang merujuk pada kepadatan atau tekstur jaringan tubuh tertentu seperti chubby, tembem, dan sebagainya yang menunjukkan secara jelas adanya tanda-tanda ketidak-adilan sosial yang dialami seorang yang memiliki tubuh sangat besar karena menghukum obesitas sebagai individu yang malas (32). Seseorang yang mengalami obesitas umumnya merasakan kondisi yang membuat tidak bahagia, dengan anggapan dapat memperparah stres (33).

Pada penelitian ini diperoleh bahwa mahasiswa yang tidak obesitas dan merasa stres (laki-laki 75,5\%; perempuan $71 \%$ ) lebih banyak dibanding yang obesitas dan merasa stres (laki-laki 63,6\%; perempuan 53,8\%). Lebih banyak persentase mahasiswa obes yang tidak merasa stres dibandingkan mereka yang non-obes dan tidak stres. Kemungkinan terdapat faktor lain yang mempengaruhi perasaan stres pada mahasiswa seperti SES yang terbukti signifikan terhadap perasaan stres pada penelitian ini. Selain itu, bahwa obesitas tidak datang mendadak sehingga stres maupun kecemasan yang ditimbulkan masih dapat diadaptasi oleh yang bersangkutan (34). Masyarakat kelas menengah ke bawah umumnya masih sulit untuk mencukupi kebutuhan pangan yang aman dan seimbang. Mereka menganggap bahwa makan yang penting tercukupi tanpa memikirkan efek samping dari makanan tersebut. Hampir sebagian siswa yang mengalami obesitas mempunyai status ekonomi menengah ke atas. Tingkat sosial ekonomi keluarga diduga mempengaruhi terjadinya obesitas karena adanya perubahan pengetahuan, sikap, perilaku, gaya hidup, dan pola makan (35). 
Penelitian ini juga menemukan bahwa tidak terdapat hubungan yang signifikan antara body image dan perasaan stres baik pada mahasiswa laki-laki maupun perempuan, meskipun analisis dengan OR menunjukkan bahwa mahasiswa yang memiliki body image negatif memiliki risiko sedikit lebih besar (1,5 kali) untuk merasa stres daripada mahasiswa yang memiliki body image positif. Body image negatif diantaranya dapat berupa kepercayaan diri yang rendah. Sementara itu, disebutkan bahwa remaja dengan kepercayaan diri yang rendah berisiko lebih besar untuk mengalami gejala stres (depresi) dan kelainan perilaku makan (36). Penelitian sebelumnya (10) menyebutkan hubungan stres akulturatif dan ketidakpuasan body image memicu eating disorder. Penelitian lain (27) juga menemukan bahwa ketidakpuasan tubuh memiliki faktor risiko yang serius terhadap eating disorder serta terdapat hubungan dua arah antara ketidakpuasan tubuh dan eating disorder. Sementara penelitian ini tidak mengidentifikasi secara khusus adanya eating disorder pada subjek.

Beberapa keterbatasan dalam penelitian ini diantaranya adalah jumlah sampel yang sedikit apabila dibandingkan jumlah populasi mahasiswa di Yogyakarta, serta desain penelitian cross sectional tidak dapat menggambarkan hubungan sebab-akibat. Meskipun demikian, hasil penelitian ini dapat digunakan sebagai dasar penelitian berikutnya untuk mencari hubungan sebab akibat antara obesitas, body image, dan perasaan stres terutama pada mahasiswa. Penelitian ini menemukan beberapa temuan yang menarik mengenai tingginya distribusi mahasiswa yang memiliki body image negatif, perasaan stres, dan obesitas berdasarkan persen lemak tubuh. Pemahaman tentang body image yang baik perlu ditanamkan kepada mahasiswa untuk menekan tingginya prevalensi body image negatif pada mahasiswa. Mahasiswa juga perlu diberikan pengetahuan lebih dalam tentang obesitas dan fakktor-faktor risiko obesitas serta gejala-gejala stres/depresi untuk menghindari risiko buruk obesitas dan stres terhadap kesehatan.

\section{SIMPULAN DAN SARAN}

Hasil penelitian ini menunjukkan terdapat hubungan signifikan antara body image dan obesitas berdasarkan PLT pada mahasiswa baik laki-laki maupun perempuan. Mahasiswa, terutama laki-laki dengan obesitas memiliki potensi lebih besar untuk mempunyai body image negatif dibandingkan mahasiswa laki-laki yang tidak obes. Tidak terdapat hubungan signifikan antara body image dan perasaan stres, serta antara obesitas dan perasaan stres, baik pada mahasiswa laki-laki maupun perempuan. Namun, mahasiswa non-obes memiliki peluang lebih besar untuk merasa stres dibandingkan mahasiswa obes, serta mahasiswa dengan body image negatif mempunyai potensi lebih besar untuk merasa stres daripada mahasiswa dengan body image positif.

Pengetahuan tentang body image yang baik perlu ditanamkan kepada mahasiswa baik laki-laki maupun perempuan. Penelitian yang akan datang diharapkan dapat mengembangkan studi serupa dan menggunakan nilai batas perasaan stres terbaru atau mengembangkan instrumen perasaan stres dengan kuesioner yang lebih sesuai untuk menggambarkan stres pada mahasiswa di Indonesia. Penting juga untuk diteliti variabel-varabel yang mempengaruhi hubungan antara obesitas, body image, dan perasaan stress.

\section{UCAPAN TERIMA KASIH}

Penulis mengucapkan terimakasih kepada Neni T Rahmawati, PhD, Rusyad A Suriyanto, MHum, dan Rianto, MEng atas dukungannya selama penelitian.

\section{RUJUKAN}

1. Kemenkes Riset kesehatan dasar: Riskesdas 2013. [serial online] 2013 [cited 2014 May 23]. Available from: URL: http://depkes.go.id

2. Soegih R, Wiramihardja KK. Obesitas: permasalahan dan terapi praktis. Jakarta: Sagung Seto; 2009.

3. Lahey BB. Maladaptive behavior: an introduction to abnormal psychology. United States of America: Scott Foresman Profesional Books; 1980.

4. Buxton BK. Body image and women: how does obesity fit into the picture?. Bariatric Nurs Surg Patient Care [serial online] 2008 [cited 2014 Oct 6];3(4). Available from: URL: http://search.proquest.com

5. Norton K, Olds T. Anthropometrica: a textbook of body measurement for sports and health courses. Adelaide: UNSW Press; 1996.

6. Tarigan N. Hubungan citra tubuh dengan status obesitas, aktifitas fisik dan asupan energi remaja SLTP di Kota Yogyakarta dan Kabupaten Bantul. Jurnal Gizi Klinik Indonesia 2005;1(3):130-6. 
7. Sabageh AO, Ogunfowokan AA, Ojofeitimi EO. Obesity and body image disrepancy among school adolescents in Ile-Ife, Osun State, Nigeria. Pak J Nutr;12(4):377-81.

8. Grober U. Mikronutrien: penyelarasan metabolik, pencegahan dan terapi. (Terjemahan) Hadinata AH, Aini N. Jakarta: EGC; 2013.

9. Insel PM. Core concepts in health. California: Mayfield Publisihing Company; 1997.

10. Aguirre CE. The Relationship between acculturative stress and body image dissastisfaction among Latina College Students [Tesis]. Nothern Illinois University [serial online] 2013 [cited 2014 Oct 10]. Available from: URL: http:// search.proquest.com

11. Siegel JM. Body image change and adolescent depressive symptoms. J Adolesc Res 2002;17:27.

12. Indra MR. Adiposit, obesitas dan masalah kesehatan global di era milenium. Surabaya: Fakultas Kedokteran Universitas Brawijaya; 2006.

13. Deurenberg P, Deurenberg-Yap MD, Wang J, Lin FP, Schmidt $\mathrm{G}$. The impact of body build on the relationship between body mass index and percent body fat. Int J Obes 1999;23:537-42.

14. Daniel WW. Biostatistics: a foundation for analysis in the health sciences. Canada: John Wiley \& Sons; 1987.

15. Budiarto E. Biostatistika untuk kedokteran dan kesehatan masyarakat. Jakarta: EGC; 2002.

16. Cohen S, Kamarck, Mermelstein R. A global measure of perceived stress. J Health Soc Behav 1983;24:385-96.

17. Cohen S, Williamson G. Perceived stress in a probability sample of the United States. 1988. In: S. Spacapam, S. Oskamp (Eds.). The social psychology of health: claremont symposium on applied social psychology. Newbury Park, CA: Sage [serial online] [cited 2014 Sep 16]; 31-67. Available from: http://www.psy.cmu.edu/.

18. Hastuti J. Anthropometry and body composition of indonesia adults: an evaluation of body image, eating behaviour, and physical activity [Tesis]. Quensland, Quensland University of Technology [serial online] 2013 [cited 2014 Sep 14]. Available from: http://eprints.qut.edu.au/61740/.

19. WHO. Physical status: the use and interpretation of anthropometry, technical report series 854. In: Hastuti J. anthropometry and body composition of indonesia adults: an evaluation of body image, eating behaviour, and physical activity [Tesis]. Quensland, Quensland University of Technology [serial online] 2013 [cited 2014 Sep 14]. Available from: http://eprints.qut.edu.au/61740/.

20. Marfell-Jones M, Olds T, Stewart A, Carter L. International standards for anthropometric assessment. South Australia: ISAK; 2006.

21. Evans C, Dolan B. Body shape questionnaire: derivation of shortened "alternate forms." Int J Eat Disord 1993;13:31521.
22. Azhari. Hubungan aktifitas fisik, kebugaran fisik dan imej tubuh dengan kejadian obesitas pada siswa SMA di Kota Banda Aceh Propinsi Nanggroe Aceh Darussalam [Tesis]. Yogyakarta: Universitas Gadjah Mada; 2007.

23. Almatsier S, Soetardjo S, Soekarti M. Gizi seimbang dalam daur kehidupan. Jakarta: PT Gramedia Pustaka Utama; 2011.

24. Nonis AS, Hudson GI, Logan LB \& Ford CW. Influence of perceived control over time on college students' stress and stress-related outcomes. Res High Educ 1998;39(5):587-605.

25. Cohen S, Janicki-Deverts D. Who's stressed? Distributions of psychological stress in the United States in probability samples from 1983, 2006 and 2009. J Appl Soc Psychol 2012;42(6):1320-34.

26. Bagrowicz R, Watabane C, Umezaki M. Is obesity contagious by way of body image? A study in Japanese female students in the United States. J Commun Health 2013;38:834-7.

27. Santana. Factors associated with body image dissastification among adolescents in public schools students in Salvador, Brazil. Nutr Hosp 2013;23(3):74755.

28. Fairburn CG. Cognitive behavior therapy and eating disorder. New York: The Guilford Press; 2008.

29. Blake CE, Hébert JR, Lee DC, Adams SA, Steck SE, Blair SN. Adults with greater weight satisfaction report more positive health behaviors and have better health status, regardless of BMI. J Obes 2013;2013:291371.

30. Indra MR, Ratnawati R, Lyrawati D, Muliartha K. Fight obesity from cells to community. Malang: Laboratorium Ilmu Faal FK UNIBRAW; 2006.

31. Kusuma MTPL. Hubungan antara status stres psikososial dengan status gizi siswa SMP Stella Duce 1 Yogyakarta. Jurnal Gizi Klinik Indonesia 2010;6(3):138-144.

32. Wathne K. Movement if large bodies impaired: the double burden of obesity: somatic and semiotic issues. Sport Educ Soc 2011;16(4):415-29.

33. Smith E, Sweeting H, Wright C. 'Do I care?' young adults' recalled experiences of early adolescent overweight and obesity: a qualitative study. Int J 2013;37:303-8.

34. Misnadiarly. Obesitas sebagai faktor risiko beberapa penyakit, ed 1. Jakarta: Pustaka Obor Populer; 2007.

35. Kurniawati D. Hubungan toleransi stres dengan kecenderungan binge eating disorder dan obesitas pada siswa SMA Muhammadiyah 1 Yogyakarta [Skripsi]. Yogyakarta: Universitas Gadjah Mada; 2007.

36. Courtney EA, Gamboz J, Johnson JG. Problematic eating behaviors in adolescents with low self-esteem and elevated depressive symptoms. Eat Behav 2008;9:408-14. 